\title{
Pasture damage and regrowth from cattle treading
}

\author{
T.N. PANDE ${ }^{1}$, I. VALENTINE ${ }^{1}$, K. BETTERIDGE ${ }^{2}$, A. MACKAY ${ }^{2}$ and D. HORNE ${ }^{1}$ \\ ${ }^{1}$ Institute of Natural Resources, Massey University, Palmerston North \\ ${ }^{2}$ AgResearch, Private Bag 11008, Palmerston North \\ ${ }^{1}$ T.N.Pande@massey.ac.nz
}

\begin{abstract}
Two experiments were conducted to describe the damage and regrowth of pasture after a single, severe cattle treading event during winter. One experiment was conducted on hill country at AgResearch's Ballantrae Hill Country Research Station, and the other on the No. 4 Dairy Unit at Massey University. Herbage growth rate, canopy cover, tiller density and leaf area index were studied and compared in grazed, cattle-trodden and untrodden (control) pastures. At Ballantrae, the control treatment was sheep-grazed pasture, and at Massey University, it was cattle-grazed, but untrodden pasture under the electric fence.

A single cattle treading event on winter-wet soils reduced hill pasture growth rates in spring to $11 \mathrm{~kg} \mathrm{DM} / \mathrm{ha} /$ day compared to $18 \mathrm{~kg} \mathrm{DM} / \mathrm{ha} /$ day in undamaged pasture on slopes, and to $21 \mathrm{~kg} \mathrm{DM} /$ ha/day compared to $39 \mathrm{~kg} \mathrm{DM} / \mathrm{ha} /$ day on tracks. Spring dairy pasture growth rate to 7 weeks after treading was $33 \mathrm{~kg} \mathrm{DM} / \mathrm{ha} /$ day compared to $51 \mathrm{~kg}$ $\mathrm{DM} / \mathrm{ha}$ /day in undamaged pasture. Damage reduced canopy cover to $60 \%$ on hill pasture tracks and to $43 \%$ in dairy pasture, compared to covers of $95 \%$ and $90 \%$ in undamaged pastures, respectively. It was concluded that the low spring herbage growth rate following a single, severe winter treading of pasture on wet soil was due mainly to significantly reduced tiller numbers, and a decrease in leaf area index and canopy cover. Treading had no significant effect on the size of individual tillers.
\end{abstract}

Keywords: cattle treading, hill country, pasture, pugging

\section{Introduction}

Grazing in wet weather combines the effects of treading and defoliation (Curl \& Wilkins 1983). Treading by grazing cattle can influence pasture composition, cover and growth rate (Sheath \& Carlson 1998). Brown \& Evans (1973) reported a reduction in pasture growth after treading treatments and suggested management practices to maintain pasture vegetation under treading stress.
Studies measuring the effects of animal treading damage on soil physical properties have shown the adverse effect on porosity and infiltration rates and corresponding increases in bulk density and aggregate size (Nguyen et al. 1998). Such changes can adversely affect the root system of the pasture plants and decrease yield (Brown \& Evans 1973; Johnson et al. 1993).

The extent of treading damage may be influenced by animal type and size, pasture cover, stocking rate and grazing duration (McCalla et al. 1984). Cattle grazing and treading can remove much of the resident vegetation (Hume \& Chapman 1993) with the extent of soil surface damage increasing when grazing residuals are reduced (Sheath \& Boom 1997); and a short-term loss in pasture density and production occurring (Sheath \& Carlson 1998).

The objectives of the two experiments described in this paper were to study damage and regrowth of late winter/spring pasture after a single, severe, winter, cattle-treading event on wet soil. The aim of this paper is to extend the descriptive information on pasture damage by such treading events and the subsequent regrowth of pasture after treading.

\section{Experimental details}

Two field studies were conducted: One at the AgResearch 'Ballantrae' Hill Country Research Station in Southern Hawke's Bay (40 $19^{\prime} \mathrm{S}$; $\left.175^{\circ} 50^{\prime} \mathrm{E}\right)$, from August to December 1998 and another at the No. 4 Dairy Unit, Massey University, Palmerston North (402'ㄱ' $175^{\circ} 37^{\prime} \mathrm{E}$ ) from August to October 1999.

\section{Soil and Pasture}

\section{Ballantrae}

The soil was a moderately steep Taihape steepland soil (J.D. Cowie, unpublished soil survey report. In: Betteridge et al. 1999) developed from siltstone. This soil is classified as yellow-grey earth/yellow-brown earth intergrade (Typic Dystrochrept) of sedimentary origin (Taylor 1949). The dominant grasses at the start of the trial were perennial ryegrass (Lolium perenne.), low fertility tolerant grasses e.g., browntop (Agrostis capillaris), sweet vernal (Anthoxanthum odoratum), and crested dogstail (Cynosurus cristata), high fertility 
responsive grasses e.g., Yorkshire fog (Holcus lanatus), poa (Poa sp.) and cocksfoot (Dactylus glomerata). White clover (Trifolium repens), the resident perennial legume, contributed about $8 \%$ of spring herbage accumulation. Average annual rainfall at the experimental site is $1200 \mathrm{~mm}$ and soil temperature at $10-\mathrm{cm}$ depth ranged from $6^{\circ} \mathrm{C}$ in August to $13^{\circ} \mathrm{C}$ in December.

\section{No.4 Dairy Unit}

The soil at the site is predominantly Tokomaru silt loam (Cowie 1972) and is classified as an Aeric Fragiaqualf (gleyed, yellow-grey earth) (Cowie et al. 1978). Total rainfall for the experimental period was $133 \mathrm{~mm}$ and average annual rainfall is $995 \mathrm{~mm}$. Average soil temperature at $10-\mathrm{cm}$ depth during the experimental period ranged from $9^{\circ} \mathrm{C}$ in August to $12^{\circ} \mathrm{C}$ in October. The dominant grasses were perennial ryegrass, browntop, Yorkshire fog and cocksfoot. These grasses together accounted for over $90 \%$ of vegetative growth.

\section{Treatments}

At Ballantrae, mature beef cows were stocked at 300 cattle/ha for $24 \mathrm{~h}$ on 20 August, 1998 when soil water content (SWC) was above the plastic limit ( $>42 \% \mathrm{w} / \mathrm{w}$ ) (Damaged). Two further cattle grazings at 150 cattle/ha for $24 \mathrm{~h}$, when SWC was $<42 \%$, occurred during the trial period. This treatment was compared with pasture grazed at 50 cattle/ha for $24 \mathrm{~h}$ only if the SWC was below $24 \%$, viz. late summer only (Undamaged). This Undamaged treatment was part of a larger, ongoing study, in its third year. At this lower moisture content, soil was not damaged by cattle treading. During the experimental period ending on 14 December, sheep grazed the Undamaged pastures over 3-day intervals, to coincide with cattle grazing on Damaged pastures, as SWC did not fall below 24\%. Each treatment plot was approximately $400 \mathrm{~m}^{2}$ (ca. $20 \mathrm{~m} \mathrm{x} 20 \mathrm{~m}$ ) in size and replicated twice using a randomised block design.

At No. 4 Dairy Unit, 150 dry dairy cattle/ha were grazed for 36 hours over four breaks in one paddock, starting on 14 August, 1999, while soils were wet (36$41 \%$ SWC). This event resulted in a range of soil damage. Eight ( $2 \mathrm{~m} \times 1 \mathrm{~m}$ ) 'high treading impact' plots were selected as the Damaged treatments. A further eight plots of the same size were established under the electric subdivision fence where pastures were cattlegrazed, but not trodden (Undamaged). After grazing of each break, the electric fence was shifted $1 \mathrm{~m}$ towards the ungrazed pasture, and cattle grazed from the opposite side.

One month after the treading event (day 29 after treading), a further grazing at 50 dairy cattle/ha for $24 \mathrm{~h}$ occurred on 12 September 1999 on all plots, while soils were dry (27-30\% SWC).

\section{Measurements}

At Ballantrae, three harvests were carried out on pasture pre-trimmed to $1 \mathrm{~cm}$ height, from $0.5 \mathrm{~m}^{2}$ randomly selected quadrats per plot for the estimation of pasture growth. Cages were placed over the pre-trimmed pasture. At each harvest, two quadrats from tracks and two quadrats from slopes were cut in each plot. Canopy cover was calculated from the number of first-hit points that touched green vegetation cover or bare ground from five, 40-pin transects, in each plot using a purpose built 'contometer' (Betteridge et al. 1999).

At No. 4 Dairy Unit, pasture-growth was measured over two 15-day periods, days 5 to 20 and days 33 to 48 after treading. At each harvest a sub-sample was used for botanical separation and measurement of leaf area. Tiller density was determined twice at (20 and 48 days after treading) from five cores $\left(82.4 \mathrm{~cm}^{2} /\right.$ core) per plot (Mitchell \& Glenday 1958). Ground cover was estimated by first-hit point quadrat on a 10 x 10 matrix, within each plot.

\section{Results}

\section{Ballantrae}

\section{Herbage growth rate}

Significant decreases in early spring herbage growth were measured on both damaged slopes and tracks, owing to severe cattle treading (Table 1). An average decrease in herbage growth rate of $18 \mathrm{~kg} / \mathrm{DM} / \mathrm{ha}$ /day on tracks and $7 \mathrm{~kg} / \mathrm{DM} / \mathrm{ha} /$ day on slopes in damaged pasture was measured during the first 7 weeks after treading (P1). Pasture growth was twice as fast on tracks compared to slopes in $\mathrm{P} 1(\mathrm{P} \leq 0.05)$. During the next 4-week period (P2), herbage growth rate was $23 \%$ and $21 \%$ lower in damaged tracks and slopes, respectively, compared to the undamaged treatment. Herbage growth rates between damaged and undamaged tracks and slopes were similar in the 11-14 week posttreading period (P3). Average herbage growth rate from all three harvests was significantly different between damaged and undamaged tracks, but not between damaged and undamaged slopes. Herbage growth rate was slower on slopes than on tracks in P1 and P2 only (Table 1).

The proportion of hillside occupied by tracks has been estimated at $21 \%$ (Betteridge et al. 1999). Using this proportion to derive a weighted estimate of pasture growth for the "average" hillside, total accumulated pasture growth on undamaged pasture over the 15week trial was $3010 \mathrm{~kg} \mathrm{DM} / \mathrm{ha}$. Damaged pasture yielded $2250 \mathrm{~kg}$ DM/ha, a $25 \%$ reduction. Relative reduction in growth owing to treading was $42 \%$ in $\mathrm{P} 1$, $22 \%$ in $\mathrm{P} 2$ and $8 \%$ in $\mathrm{P} 3$. 
Table 1 Mean herbage growth rate ( $\mathrm{kg} \mathrm{DM} / \mathrm{ha} /$ day) and first hit canopy cover (\%) in tracks and slopes of undamaged (Undam) and damaged (Dam) hill pasture at Ballantrae.

\begin{tabular}{|c|c|c|c|c|c|c|c|c|c|}
\hline \multirow{3}{*}{$\begin{array}{c}\text { Date damaged } \\
20 / 08 / 98\end{array}$} & \multicolumn{4}{|c|}{$\begin{array}{l}\text { Herbage growth rate } \\
\text { (kg DM/ha/day) }\end{array}$} & & \multicolumn{4}{|c|}{ Canopy cover (\%) } \\
\hline & \multicolumn{2}{|c|}{----- Track ----- } & \multicolumn{2}{|c|}{----- Slope ----- } & \multirow[t]{2}{*}{ Date measured } & \multicolumn{2}{|c|}{---- Track ----- } & \multicolumn{2}{|c|}{---- Slope ---- } \\
\hline & Undam & Dam & Undam & Dam & & Undam & Dam & Undam & Dam \\
\hline $24 / 8 / 98$ to $12 / 10 / 98$ (P1) & 39 & 21 & 18 & 11 & 2/9/98 & 95 & 60 & 97 & 91 \\
\hline $16 / 10 / 98$ to $16 / 11 / 98$ (P2) & 54 & 42 & 33 & 26 & $22 / 10 / 98$ & 99 & 96 & 100 & 98 \\
\hline $20 / 11 / 98$ to $14 / 12 / 98$ (P3) & 33 & 29 & 31 & 29 & $24 / 11 / 98$ & 100 & 94 & 100 & 98 \\
\hline \multicolumn{10}{|l|}{ Statistical significance ${ }^{1}$} \\
\hline P1 & \multicolumn{2}{|c|}{ * } & \multicolumn{2}{|c|}{ * } & $2 / 9 / 98$ & \multicolumn{2}{|c|}{$* \star *$} & \multicolumn{2}{|c|}{ * } \\
\hline $\mathrm{P} 2$ & \multirow{2}{*}{\multicolumn{2}{|c|}{$\begin{array}{l}\text { NS } \\
\text { NS }\end{array}$}} & \multicolumn{2}{|c|}{ NS } & $22 / 10 / 98$ & \multicolumn{2}{|c|}{ NS } & \multicolumn{2}{|c|}{ NS } \\
\hline P3 & & & \multicolumn{2}{|c|}{ NS } & $24 / 11 / 98$ & \multicolumn{2}{|c|}{$* * *$} & \multicolumn{2}{|c|}{ NS } \\
\hline Dam vs. Undam averaged & \multicolumn{2}{|c|}{ * } & \multicolumn{2}{|c|}{ NS } & Dam vs. Undam & \multicolumn{2}{|c|}{$* * *$} & \multicolumn{2}{|c|}{ NS } \\
\hline Period averaged & \multicolumn{2}{|c|}{$* * *$} & \multicolumn{2}{|c|}{$* * *$} & Date & \multicolumn{2}{|c|}{$* * *$} & \multicolumn{2}{|c|}{$* *$} \\
\hline Interaction (DamPeriod) & \multicolumn{2}{|c|}{ NS } & \multicolumn{2}{|c|}{ NS } & $\begin{array}{c}\text { Interaction } \\
\text { (Dam vs. Date) }\end{array}$ & \multicolumn{2}{|c|}{$* \star *$} & \multicolumn{2}{|c|}{ NS } \\
\hline
\end{tabular}

\section{Canopy cover}

Canopy cover of damaged hill pasture was $35 \%$ and $6 \%$ lower on tracks and slopes, respectively, compared to undamaged pastures 1 week after treading (Table 1). Seven weeks later, canopy cover in both damaged tracks and slopes had recovered to $96-98 \%$ of undamaged pasture, but decreased marginally again on damaged tracks in November. Cover was lower in September than either October or November (Table 1).

Using the weighting for the proportion of total area occupied by tracks (above), reduction in canopy cover owing to treading was $13 \%, 2 \%$ and $3 \%$ for P1, P2 and $\mathrm{P} 3$, respectively.

\section{No. 4 Dairy Unit}

Herbage growth rate

There was no growth rate difference during the first 15day growth period (days 5-20, after treading) between damaged and undamaged pasture, as little growth occurred (Table 2). In the subsequent 15-day growth period (days 33-48) there was a 44\% decrease in growth rate on damaged compared to undamaged pasture.

\section{Tiller density and leaf area index (LAI)}

Twenty days after treading, the mean tiller density was 2250 tillers $/ \mathrm{m}^{2}$ in damaged pasture compared to 9050 tillers $/ \mathrm{m}^{2}$ in undamaged pasture (Table 2). In the second growth period, tiller density in damaged pasture tended to increase compared to undamaged pasture, but the difference in tiller density owing to damage at 48 days still remained.

LAI was significantly $(\mathrm{P} \leq 0.001)$ lower in damaged pastures compared to undamaged pastures for both day 20 and day 48 measurements.

\section{Canopy cover}

Twenty days after treading (3 September, 1998), canopy cover of damaged pasture was $43 \%$ compared to $90 \%$ in

Table 2 Mean ${ }^{1}$ herbage growth rate ( $\left.\mathrm{kg} \mathrm{DM} / \mathrm{ha} / \mathrm{day}\right)$, tiller density (tillers $\left./ \mathrm{m}^{2}\right)$, leaf area index (LAl), tiller size (mg) and canopy cover (\%) of undamaged (Undam), and damaged (Dam) dairy pasture at No. 4 Dairy Unit, Massey University.

\begin{tabular}{|c|c|c|c|c|c|c|c|c|c|c|c|}
\hline \multirow{2}{*}{$\begin{array}{l}\text { Date Damaged } \\
14 / 08 / 99 \\
\text { Date measured } \\
3 / 9 / 99(15)^{2}\end{array}$} & \multirow{2}{*}{$\begin{array}{c}\text { Days after } \\
\text { treading } \\
\\
20\end{array}$} & \multicolumn{2}{|c|}{$\begin{array}{c}\text { Herbage growth } \\
\text { rate } \\
\text { (kg DM/ha/day) }\end{array}$} & \multicolumn{2}{|c|}{$\begin{array}{l}\text { Tiller density } \\
\left(\text { Tillers } / \mathrm{m}^{2}\right)\end{array}$} & \multicolumn{2}{|c|}{$\begin{array}{c}\text { Leaf Area Index } \\
\text { (units) }\end{array}$} & \multicolumn{2}{|c|}{$\begin{array}{l}\text { Tiller size } \\
\quad(\mathrm{mg})\end{array}$} & \multicolumn{2}{|c|}{$\begin{array}{c}\text { Canopy cover } \\
(\%)\end{array}$} \\
\hline & & $\begin{array}{l}\text { Undam } \\
3\end{array}$ & $\begin{array}{c}\text { Dam } \\
-2\end{array}$ & $\begin{array}{l}\text { Undam } \\
9050\end{array}$ & $\begin{array}{l}\text { Dam } \\
2250\end{array}$ & $\begin{array}{c}\text { Undam } \\
1.18\end{array}$ & $\begin{array}{l}\text { Dam } \\
0.34\end{array}$ & $\begin{array}{c}\text { Undam } \\
8.6\end{array}$ & $\begin{array}{l}\text { Dam } \\
12.2\end{array}$ & $\begin{array}{l}\text { Undam } \\
\quad 90\end{array}$ & $\begin{array}{c}\text { Dam } \\
43\end{array}$ \\
\hline $1 / 10 / 99(15)^{2}$ & 48 & 59 & 33 & 7140 & 4590 & 2.73 & 1.97 & 24.2 & 24.9 & 99 & 82 \\
\hline
\end{tabular}

Statistical significance ${ }^{3}$

$\begin{array}{lcccc}3 / 9 / 99 & \text { NS } & * * * & * * * & \text { NS } \\ 1 / 10 / 99 & * * & * * & \text { NS } \\ \begin{array}{l}\text { Dam vs. Undam } \\ \text { averaged }\end{array} & * & * * * & \text { NS }\end{array}$

${ }^{1}$ Least Square mean, ${ }^{2}$ Days of regrowth, ${ }^{3 *},{ }^{* *},{ }^{* * *}=$ means are significantly different at $5 \%, 1 \%$ and $0.1 \%$ levels of probability. NS $=$ means are not significantly different. 
undamaged pasture (Table 2). Canopy cover in damaged pasture recovered to $82 \%$ but was still lower than the 99\% cover in undamaged plots, at day 48 measurement. The loss of tiller number and leaf area in damaged plots, compared to undamaged plots, was reflected in a canopy cover reduction at both 20 and 48 days.

\section{Tiller size}

In contrast to tiller number, the size of individual tillers showed no difference to treading, being similar between damaged and undamaged pastures at either 20 or 48 days after treading (Table 2).

\section{Herbage mass vs. Leaf area index}

There was a significant linear relationship between herbage mass and LAI of undamaged pasture $\left(\mathrm{R}^{2}=0.99\right.$, $\mathrm{P} \leq 0.01, \mathrm{n}=8)$ and between herbage mass and LAI of damaged pasture $\left(\mathrm{R}^{2}=0.99, \mathrm{P} \leq 0.02, \mathrm{n}=8\right)$ at three harvests (Figure 1). The relationship between herbage mass and LAI was the same for both treatments. LAI increased over the first regrowth period in damaged pasture but did not change in undamaged pasture (Figure 2). At 33 days after treading (4 days after the 2nd grazing), the two treatments followed the same LAI pathway. The loss, then recovery, of leaf area following grazing and treading can explain the herbage mass differences observed.

Correlation between tiller density and LAI, tiller density and canopy cover, and LAI and canopy cover

There was strong correlation $(\mathrm{r}=0.80, \mathrm{P} \leq 0.001)$ between tiller density and LAI at day 20 but there was no correlation between them 48 days after treading. The correlation between tiller density and canopy cover was strong $(\mathrm{r}=0.86, \mathrm{P} \leq 0.001)$ at day 20 and $(\mathrm{r}=0.76$, $\mathrm{P} \leq 0.001)$ at day 48 after treading. The correlation between canopy cover and LAI at day 20 was stronger $(\mathrm{r}=0.78, \mathrm{P} \leq 0.001)$ than at day $48(\mathrm{r}=0.56, \mathrm{P} \leq 0.05)$.

\section{Discussion}

The reduction in herbage yield of damaged pasture immediately after treading and its regrowth agree with the findings of Edmond (1964). The results of this study showed that a single, severe, treading event on winter-wet soils caused effects, that carried over into spring. The growth reduction for the 49-day period following treading for the hill pasture was $42 \%$, comprising of a $47 \%$ reduction in growth on hill tracks, and a $37 \%$ reduction on hill slopes. The reduction in pasture growth was similar for the dairy pasture $(50 \%)$ for the same interval following the treading damage. This is considerably less than that recorded by others using artificially high-intensity treading (e.g., Brown
Figure 1 Relationship between herbage mass $\left(\mathrm{kg} \mathrm{DM} / \mathrm{m}^{2}\right)$ and $\mathrm{LAI}$ of undamaged and damaged pasture on days 20 , 33 and 48 after treading (vertical bars show S.E.M.). Arrows indicate passage of time. * - Two LAI values overlap.

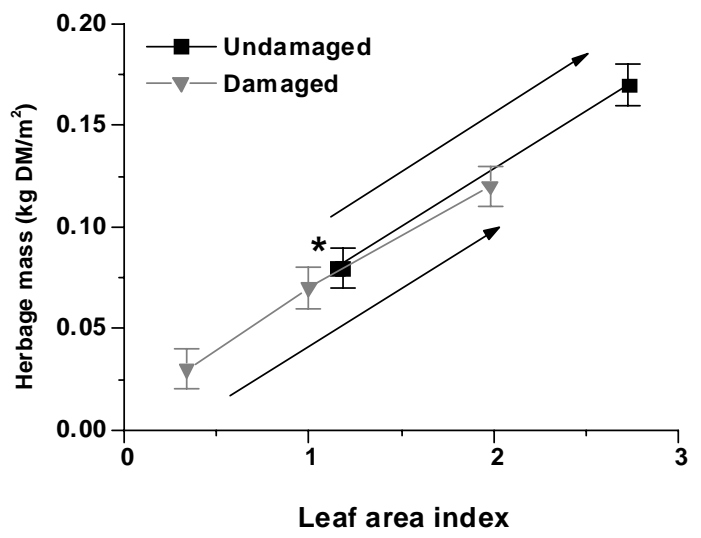

Figure 2 The change of leaf area index between damaged and undamaged pasture on days 20,33 and 48 after treading (vertical bars show S.E.M.).

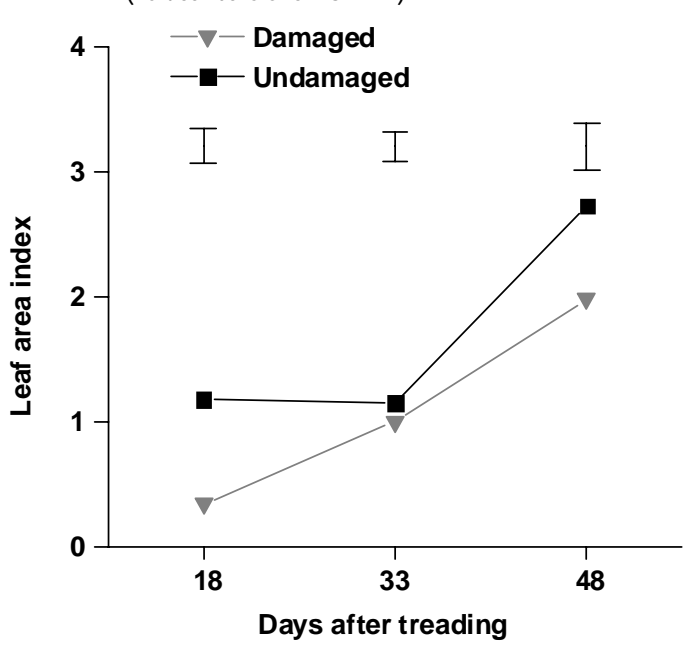

\& Evans (1973), recorded a 64\% reduction in herbage growth), but similar on hill slopes and more on hill tracks than the reduction of $5-10 \mathrm{~kg} \mathrm{DM} / \mathrm{ha} / \mathrm{day}$, reported by Sheath \& Carlson (1998).

The main effect of treading damage on herbage growth appears to have been through loss of canopy cover (and LAI), owing to destruction of plant physical parts. Damage to growing points and tillers leads to a lower leaf area index, which in turn leads to a lower growth of herbage mass. Brown \& Evans (1973) believed the effect of treading was owing to the direct damage to plant growing points, uprooting and breaking of the tillers by hoof action and loss of photosynthetic surfaces. 
The degree of yield reduction during $\mathrm{P} 1$ and $\mathrm{P} 2$ at Ballantrae was similar for slope and track classes of hill pasture, while the cover differences were present in slope and track classes at 2 September (only 10 days after treading).

Whereas tracks are the predominant zone for cattle treading in hill country, at the very high stocking intensity used in this trial, significant damage occurred on slopes. The reason for better canopy cover on damaged slopes than damaged tracks was probably owing to the high browntop and white clover content on slopes compared with less dense, high fertility grasses on tracks (unpublished data).

Even though growth rates in the 11-14-week period following treading were only $8 \%$ greater in undamaged pasture, the loss of pasture growth owing to treading damage over the whole 14 weeks of the study was $25 \%$. This loss would have a significant impact on lactating beef cows during this period.

Results from the dairy pasture experiment demonstrated that reduced tiller density, leaf area, and therefore canopy cover, were responsible for the decrease in herbage growth rate owing to treading. These data also show that tiller density and LAI were the pasture components that determined canopy cover and that these were significant controllers of herbage growth rate. The strong linear relationship between herbage mass of both undamaged and damaged pasture with LAI suggests that tiller density and LAI can be used to predict herbage growth. Data in Figure 1 suggest that the relationship between LAI and mass is not affected by treading.

The unaffected growth rate of individual tillers on No. 4 Dairy (Table 2) suggests that soil factors and above-ground competition for space did not affect pasture production after treading damage. There was a difference in tiller size between damaged pasture compared to undamaged pasture 20 days after treading, but size was not significantly different at either 20 or 48 days following treading.

The key in understanding variability in herbage growth rate after treading is the change in tiller density and LAI during the treading/grazing event. Stock density and grazing duration are the dominant factors for the determination of pasture cover. The negative mean herbage growth rate in damaged pasture during P1 was probably owing to the decreased tiller number (death of uprooted and broken tillers by hoof action). The increased herbage growth rate of damaged pasture in P2 (after the second grazing) was associated with an increased tiller number and LAI, but in undamaged pasture only LAI had increased. This might have been owing to the presence of treading-created open spaces.
Treading damage resulted in the death of substantial numbers of tillers. Herbage growth rate was found to be dependant upon surviving tiller density, residual leaf area and canopy cover following treading, since tiller size was unaltered by treading (Table 2). The results of this study support the evidence of Clements (1989) that plant growing points are destroyed by trampling; of Brown \& Evans (1973) that treading could effect plant growing points and photosynthetic surfaces; and of Charles (1979) that treading can act directly on the plants in the sward, damaging or destroying growing points, leaves, stems and roots.

Recovery of canopy cover during the P2 growth period at Ballantrae did not result in recovery of herbage growth rate in damaged pasture, therefore canopy cover alone cannot account for pasture growth rate. It must be assumed in that trial, that tillers were also lost, but this was not measured. The correlation between tiller density and LAI, and between canopy cover and LAI at No.4 Dairy Unit became weaker with increased canopy cover, but there was strong correlation between tiller density and canopy cover at all the times.

\section{Conclusion}

Herbage mass, tiller density and leaf area index were greater in undamaged pasture than in treading-damaged pasture. This in turn reduced canopy cover. Growth rates of tillers that survived the treading did not seem to be affected. The reduction in spring pasture production could be accounted for by the loss of pasture cover. The results indicate that to ensure stability of herbage growth in winter-grazed and spring-grazed swards, management should be directed to avoiding treading damage so as to maintain tiller density and leaf area index at the highest level possible. It is unknown whether leaf growth processes on partly damaged or buried tillers contribute to pasture recovery. Further study is needed to examine the fate of buried plant material and the source of new tillers.

\section{ACKNOWLEDGEMENTS}

We thank Des Costall for his invaluable technical support, Yvonne Gray and staff of the Herbage Laboratory, AgResearch, for dissection of the samples, Mark Osborne and Roger Levy, PGU, Massey University for technical assistance. We thank Gareth Evans for managing the pasture at No.4 Dairy Unit.

\section{REFERENCES}

Betteridge, K.; Mackay, A.D.; Shepherd, T.G.; Barker, D.J.; Budding, P.J.; Devantier, B.P.; Costall, D.A. 
1999. Effect of cattle and sheep treading on surface configuration of a sedimentary hill soil. Australian Journal of Soil Research 37: 743-760.

Brown, K.R.; Evans, P.S. 1973. Animal treading: A review of the work of the late D.B. Edmond. New Zealand Journal of Experimental Agriculture 1: 217-226.

Charles, A.H. 1979. Treading as a factor in sward deterioration. pp. 137-140. In: Changes in sward composition and productivity. Charles, A.H.; Haggar, R.J. Eds. British Grassland Society, Hurley, Maidenhead, UK.

Clements, R.J. 1989. Rates of destruction of growing points of pasture legumes by grazing cattle. XVI International Grassland Congress, Nice, France: 1027-1028.

Cowie, J.D. 1972. Soil and agriculture of Kairanga Country, North Island, New Zealand. Soil Bureau Bulletin No. 33. DSIR, Wellington.

Cowie, J.D.; Kear, B.S.; Orbell, G.E. 1978. Soil map of Kairanga Country, North Island, New Zealand. Scale 1:63 360 N.Z. Soil Bureau map 102.

Curll, M.L.; Wilkins R.J. 1983. The comparative effects of defoliation, treading and excreta on a Lolium perenne-Trifolium repens pasture grazed by sheep. Journal of Agricultural Science, Cambridge 100: 451-460.

Edmond, D.B. 1964. Some effects of sheep treading on the Growth of 10 Pasture Species. New Zealand Journal of Agricultural Research 7: 1-16.
Hume, D.E.; Chapman, D.F. 1993. Oversowing of five grass species and white clover on a Taupo hill country pumice soil. New Zealand Journal of Agricultural Research 36: 309-322.

Johnson, R.J.; McCallum, D.A.; Thomson, N.A. 1993. Pasture renovation after winter pugging damage. Proceedings of the New Zealand Grassland Association 55: 143-146.

McCalla, G.R.; Blackburn, W.H.; Merril, L.B. 1984. Effects of livestock grazing on infiltration rates. Edwards Plateau of Texas. Journal of Range Management 37: 265-269.

Mitchell, K.J.; Glenday A.C. 1958. The tiller population of pastures. New Zealand Journal of Agricultural Research 1: 305-318.

Nguyen, M.L.; Sheath G.W.; Smith C.M.; Cooper A.B. 1998. Impact of cattle treading on hill land 2. Soil physical properties and contaminant runoff. New Zealand Journal of Agricultural Research 41: 279-290.

Sheath, G.W.; Boom C.J. 1997. Impact of beef cattle grazing systems on treading damage and forage supply. Proceedings of the New Zealand Grassland Association 59: 87-92.

Sheath, G.W.; Carlson, W.T. 1998. Impact of cattle treading on hill land 1. Damage patterns and pasture status. New Zealand Journal of Agricultural Research 41: 271-278.

Taylor, N.H. 1949. Soil survey and classification in New Zealand. Proceedings of the $7^{\text {th }}$ Pacific Science Congress 6: 103-113. 